\title{
Total Jamur dan Identifikasi Yeast pada Limbah Kubis Fermentasi dengan Penambahan Vitamin dan Mineral
}

\author{
Cahya Setya Utama*, Bambang Sulistiyanto, Kezia Naomi Christy Ginting \\ Laboratorium Teknologi Pakan, Departemen Peternakan \\ Fakultas Peternakan dan Pertanian, Universitas Diponegoro, Semarang \\ Jl. Prof. Soedarto No.13, Tembalang, Kec. Tembalang, Kota Semarang, Jawa Tengah 50275 \\ *E-mail koresponden: cahyasetyautama@gmail.com
}

(Diterima 21-05-2020; disetujui 18-09-2020)

\begin{abstract}
ABSTRAK
Penelitian bertujuan mengkaji peningkatan kualitas limbah kubis fermentasi dengan penambahan vitamin dan mineral dilihat dari kandungan total jamur dan identifikasi yeast. Metode penelitian menggunakan rancangan acak lengkap (RAL) pola searah dengan 5 perlakuan dan 3 ulangan. Pengolahan data pada parameter total jamur diolah menggunakan anova, jika ada pengaruh yang nyata dilanjutkan uji duncan, sedangkan pada parameter identifikasi yeast menggunakan metode deskriptif. Penelitian menunjukkan bahwa penambahan vitamin dan mineral berpengaruh nyata $(\mathrm{P}<0,05)$ terhadap total jamur yang dihasilkan. Total jamur terbanyak pada perlakuan penambahan vitamin dan mineral $10 \%$ dengan rata-rata total jamur $71,33 \times 10^{4} \mathrm{CFU} / \mathrm{g}$. Pengecatan gram pada identifikasi jenis yeast didapatkan bentuk oval, soliter dan gram positif (yeast) menunjukkan identifikasi jenis yeast yang tumbuh yaitu Saccharomyces cerevisiae. Simpulan penelitian adalah penambahan vitamin dan mineral sebanyak $10 \%$ mampu meningkatkan kualitas limbah kubis fermentasi dilihat dari kandungan total jamur dan jenis yeast.
\end{abstract}

Kata kunci: fermentasi, jamur, limbah kubis, pengecatan gram, yeast

\begin{abstract}
The study aimed to evaluate the quality improvement of fermented cabbage waste which was added by vitamins and minerals by observing the total fungus and type of yeast. The method used was a completely randomized design (CRD) unidirectional pattern, with 5 treatments and 3 replications. Statistical analysis of total fungus was processed by ANOVA and continued by the Duncan Multiple Renge test, and the data type of yeast was discussed descriptively. The result showed, the addition of vitamin and mineral treatment significantly influenced the number of fungi $(\mathrm{P}<0,05)$. The highest number of fungus was shown beside $10 \%$ supplementation of vitamins and minerals (7.33 x $104 \mathrm{CFU} / \mathrm{g})$. Gram coloring on the identification of yeast types obtained oval, solitary, and gram-positive (yeast) it shows that the identification of the growing yeast type, Saccharomyces cerevisiae. The conclusion of the addition of $10 \%$ vitamins and minerals can improve the quality of 2 days cabbage waste fermentation seen from the total fungus and the type of yeast that grows.
\end{abstract}

Key Words: cabbage waste, fermentation, gram paintings, yeast

\section{PENDAHULUAN}

Kubis adalah salah satu sayuran yang sering dimanfaatkan untuk berbagai keperluan. Kubis memiliki kandungan karbohidrat, protein, lemak, vitamin, mineral dan mengandung bakteri asam laktat (Edam, 2018; Utama et al., 2018). Kandungan nutrisi kubis mentah dalam $100 \mathrm{~g}$ sebagai berikut: $25 \mathrm{kal}$ kalori; $1,7 \mathrm{~g}$ protein; $0,2 \mathrm{~g}$ lemak; 5,3 g karbohidrat; $64 \mathrm{mg}$ kalsium; $26 \mathrm{mg}$ fosfor; 0,7 $\mathrm{mg} \mathrm{Fe} ; 8 \mathrm{mg} \mathrm{Na}, 0,3 \mathrm{mg}$ niasin, $0,9 \mathrm{~g}$ serat, 0,7 $\mathrm{g}$ abu, $75 \mathrm{Sl}$ vitamin $\mathrm{A}, 0,1 \mathrm{mg}$ vitamin $\mathrm{Bl}$, C $62 \mathrm{mg}$ vitamin, dan 91-93\% air (Wahyuni et al., 2016). Kubis merupakan salah satu sayuran yang mudah busuk dan rusak sehingga menghasilkan limbah serta polusi (bau) (Aliya et al., 2017).

Limbah kubis dapat diolah melalui proses fermentasi. Fermentasi dapat meningkatkan kualitas nutrien, dan utilitas limbah kubis (Juwandi et al., 2018; Purwati dan Danang, 2018). Ketersediaan nutrient pada media fermentasi dapat meningkatkan 
hasil fermentasi menjadi lebih baik (Santosa et al., 2019). Fermentasi kubis mengandung bakteri asam laktat, Rhizopus sp. dan Saccharomyces sp. (Siregar et al., 2015; Utama et al., 2018 ; Cici et al., 2019).

Saccharomyces cerevisiae dapat berperan sebagai additive pakan dan bermanfaat memperbaiki pencernaan ternak. Saccharomyces cerevisiae berperan sebagai probiotik di dalam saluran pencernaan dan mampu menekanan pertumbuhan mikrooganisme patogen didalam usus (Sumardi et al., 2019). Dinding sel Saccharomyces cerevisiae mengandung manosa yang dapat meningkatkan jumlah vili usus dan sel goblet, sehingga mampu melindungi permukaan usus dari masukknya bakteri pathogen (Brummer et al., 2010). Saccharomyces cerevisiae juga berfungsi sebagai immunostimulan bagi tubuh ternak (Manoppo \& Magdalena, 2016). Saccharomyces cerevisiae terbukti dapat membunuh mikrooganisme pathogen dengan memproduksi racun polipeptida (El-Banna et al., 2011). Dosis yang aman pada pemberian Saccharomyces cerevisiae pada pakan adalah $200 \mathrm{~g} / 100 \mathrm{~kg}$ (Hastuti, 2012).

Peningkatan populasi Saccharomyces cerevisiae dalam proses fermentasi membutuhkan mikronutrien spesifik seperti vitamin dan mineral. Ketersediaan mikroogganisme dapat memicu aktivitas fermentasi yang mengakibatkan terjadinya pertambahan air sehingga kecernaan bahan fermentasi meningkat secara signifikan (Nasiu et al., 2020). Penambahan $\mathrm{CuSO}_{4}$ membantu Saccharomyces memecah fenol dalam pembentukkan lignin dengan cara menghasilkan enzim Lakase (Nurika et al., 2018).

Tembaga merupakan salah satu mikronutien penting yang dibutuhkan untuk menghasilkan enzim Lakase di dalam jamur (Usha et al., 2014). Enzim Lakase dapat berperan dalam pembuatan bioetanol (Hanung et al., 2013). $\mathrm{NaCl}$ dan $\mathrm{Mn}^{2+}$ mampu meningkatkan pertumbuhan asam laktat (Edam, 2018). $\mathrm{MnSO}_{4}$ dan $\mathrm{CaCl}_{2}$ dapat meningkatkan produksi enzim Inulinase dengan memecah inulin menjadi monomer-monomer fruktosa sehingga yeast akan terinduksi dan tumbuh (Abdianti et al., 2017; Saraswati et al., 2017). Selain mineral, Saccharomyces juga membutuhkan vitamin untuk pertumbuhannya. Vitamin bekerja sebagai pengatur proses metabolisme dan merupakan nutrient bagi mikrooganisme selama proses fermentasi (Angkasa, 2017). Kusmiati et al. (2011), menyatakan bahwa penambahan vitamin B kompleks dapat meningkatkan populasi Saccharomyces cerevisiae.

Kebaharuan penelitian ini adalah produk limbah kubis fermentasi dengan penambahan vitamin dan mineral diharapkan dapat menjadi additive pakan yang dapat meningkatkan produktivitas ternak. Tujuan penelitian adalah mengkaji penambahan vitamin dan mineral pada fermentasi limbah kubis dilihat dari total jamur dan identifikasi jenis yeast. Manfaat penelitian adalah memberikan informasi tentang adanya pengaruh penambahan vitamin dan mineral dalam limbah kubis fermentsi terhadap peningkatan jumlah jamur dan jenis yeast, serta memberikan solusi terhadap pengolahan limbah sayuran.

\section{MATERI DAN METODE}

\section{Materi Penelitian}

Materi yang digunakan terdiri dari limbah kubis, limbah kubis fermentasi, garam, molases, aquades, Sabouroud Glucosa Agar (SGA), yodium, kristal violet, lugol, alkohol 70\%, 0,72 g ( $\mathrm{CoSO}_{4}$, $\left.\mathrm{KAl}\left(\mathrm{So}_{4}\right)_{2}, \mathrm{Na}_{2} \mathrm{SeO}_{3}\right) ; 3,04 \mathrm{~g}\left(\mathrm{H}_{3} \mathrm{BO}_{3}, \mathrm{Na}_{2} \mathrm{MaO}_{4}\right.$, vitamin $\mathrm{C}$, vitamin $\mathrm{E}$, vitamin $\mathrm{B}$ kompleks); 0,5 $\mathrm{Co}\left(\mathrm{NH}_{2}\right)_{2} ; 0,5 \mathrm{~g} \mathrm{NaCl} ; 3$ g MgSO $4 ; 0,5 \mathrm{~g} \mathrm{MnSO}_{4}$; 0,5 $\mathrm{g} \mathrm{ZnSO}_{4} ; 0,1 \mathrm{~g} \mathrm{CaCl}_{2} ; 0,1 \mathrm{~g} \mathrm{FeSO}_{4} ; 0,1$ g CuSO 4 ; $1 \mathrm{~g}$ mono sodium glutamate (MSG) dengan masingmasing level pemberian yaitu $0 \%, 2,5 \%, 5 \%, 7,5 \%$, dan $10 \%$. Peralatan yang digunakan adalah alat pencacah, autoclave (ALL American USA), gelas ukur (Schott Duran, Germany), timbangan digital ketelitian 0,1 gr (Ohaous, USA), blender, alat saring, cawan petri, ose/jarum, dan $\mathrm{pH}$ meter (Crison, Spain).

\section{Metode Penelitian}

Rancangan penelitian yang digunakan adalah rancangan acak lengkap (RAL). Perlakuan yang diberikan adalah perbedaan jumlah vitamin dan mineral yang diberikan yaitu T0 (tanpa penambahan), $\mathrm{T} 1$ (2,5\% penambahan vitamin dan mineral), T2 (5\% penambahan vitamin dan mineral), $\mathrm{T} 3 \quad(7,5 \%$ penamahan vitamin dan mineral), dan $\mathrm{T} 4$ (10\% penambahan vitamin dan mineral) dengan 3 ulangan pada masing-masing perlakuan. Parameter yang diamati adalah total jamur dan jenis yeast.

\section{Prosedur Penelitian}

Prosedur penelitian diawali dengan mencacah limbah kubis dan mencapur dengan 6,7\% molases dan $8 \%$ garam dari total berat segar limbah kubis kemudian difermentasi selama 6 hari dengan 
keadaan anaerob fakultatif (Utama, et al., 2018a). Setelah enam hari dilakukan penambahan vitamin dan mineral sesuai dengan perlakuan. Perlakuan terdiri dari penambahan vitamin mineral sebanyak $0 \%, 2,5 \%, 5 \%, 7,5 \%$ dan $10 \%$ dari berat sampel dan difermentasi kembali selama dua hari. Limbah kubis fermentasi kemudian dipanen dan dilakukan pengambilan sampel untuk pengujian sampel total jamur dan identifikasi yeast.

\section{Pengambilan Data Penelitian}

Pengambilan data pada total jamur menggunakan metode hitung cawan (Total Plate Count) yang merupakan metode penentuan total jamur secara keseluruhan dalam suatu bahan menggunakan media Sabouroud Glucosa Agar (SGA) (Nurdianto et al., 2015). Sedangkan pengambilan data identifikasi yeast dilakukan dari analisis pengecatan gram dan melihat morfologi dari yeast (Bulele et al., 2019).

\section{Analisis Data}

Data yang telah diperoleh diuji menggunakan analisis ragam untuk parameter total jamur. Kemudian data diolah menggunakan program Excel 2016 dan didukung dengan analisis program SPSS versi 22. Untuk mengetahui adanya pengaruh perlakuan terhadap parameter dan dilanjutkan dengan Uji Wilayah Berjarak Duncan dengan taraf 5\% (Embarsari et al, 2015). Data pengecatan gram jamur dianalisis deskripsi yaitu data disajikan dalam bentuk tabel, dan hasilnya diintepretasikan untuk diambil kesimpulan (Sari, 2014).

\section{HASIL DAN PEMBAHASAN}

\section{Total Jamur}

Hasil penelitian limbah kubis fermentasi dengan penambahan vitamin dan mineral berbeda nyata $(\mathrm{P}<0,05)$ pada total jamur. Penelitian menunjukkan penambahan vitamin dan mineral pada limbah kubis fermentasi mempengaruhi pertumbuhan jamur. Nurdianto et al. (2015) menyatakan bahwa pertumbuhan total jamur dipengaruhi oleh ketersediaan nutrisi, suhu, air, dan oksigen. Total jamur dapat digunakan sebagai parameter penentu kualitas suatu produk. Wulandari et al. (2017) menyatakan bahwa total jamur digunakan sebagai parameter menentukan baik atau buruknya kualitas produk yang dihasilkan. Tabel 1 menggambarkan banyaknya jamur yang tumbuh dan cepatnya reaksi fermentasi yang berlangsung. Nilai rataan total jamur pada fermentasi limbah kubis tertinggi pada penambahan vitamin dan mineral 10\%. Hal ini disebabkan karena penambahan vitamin dan mineral mempengaruhi perkembangan jamur. Astuti \& Nengah (2013) menyatakan bahwa nutrisi lengkap yang dibutuhkan jamur untuk tumbuh adalah karbohidrat, protein, lemak, mineral, dan vitamin. Vitamin dan mineral berfungsi sebagai nutrient yang membantu proses fermentasi. Rostini et al (2019) menyatakan bahwa fungsi vitamin dan mineral yaitu untuk mengaktivasi enzim yang terlibat di dalam pakan fermentasi. Salah satu mineral yang membantu penyerapan glukosa dan asam amino kedalam sel adalah mineral $\mathrm{Cr}$ (Kurnia et al., 2012).

Tabel 1. Kandungan total jamur pada limbah kubis fermentasi dengan penambahan vitamin dan mineral

\begin{tabular}{|c|c|c|c|c|c|}
\hline \multirow{2}{*}{ Ulangan } & \multicolumn{5}{|c|}{ Perlakuan } \\
\hline & T0 & $\mathrm{T} 1$ & $\mathrm{~T} 2$ & $\mathrm{~T} 3$ & $\mathrm{~T} 4$ \\
\hline \multicolumn{6}{|c|}{ 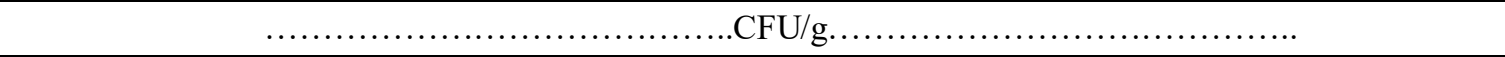 } \\
\hline U1 & $1 \times 10^{4}$ & $1 \times 10^{4}$ & $25 \times 10^{4}$ & $53 \times 10^{4}$ & $87 \times 10^{4}$ \\
\hline $\mathrm{U} 2$ & $6 \times 10^{4}$ & 0 & $7 \times 10^{4}$ & $2 \times 10^{4}$ & $78 \times 10^{4}$ \\
\hline $\mathrm{U} 3$ & $2 \times 10^{4}$ & $9 \times 10^{4}$ & $24 \times 10^{4}$ & $30 \times 10^{4}$ & $49 \times 10^{4}$ \\
\hline Rataan & $3,00 \pm 2,64^{\mathrm{d}}$ & $3,33 \pm 4,93^{\mathrm{d}}$ & $18,66 \pm 10,11^{\mathrm{c}}$ & $28,33 \pm 25,54^{b}$ & $71,33 \pm 19,85^{\mathrm{a}}$ \\
\hline
\end{tabular}

Keterangan :

Huruf a,b,c sebagai superskrip yang berbeda nyata pada baris yang sama menunjukkan perbedaan nyata $(\mathrm{P}<0,05)$

$\mathrm{T} 0=$ Fermentasi limbah kubis tanpa penambahan vitamin dan mineral

$\mathrm{T} 1=$ Fermentasi limbah kubis dengan penambahan vitamin dan mineral 2,5\%

$\mathrm{T} 2=$ Fermentasi limbah kubis dengan penambahan vitamin dan mineral $5 \%$

$\mathrm{T} 3=$ Fermentasi limbah kubis dengan penambahan vitamin dan mineral 7,5\%

T4= Fermentasi limbah kubis dengan penambahan vitamin dan mineral 10\% 


\section{Jenis Yeast}

Hasil penelitian limbah kubis fermentasi dengan penambahan vitamin dan mineral menunjukkan adanya yeast jenis Saccharomyces cerevisiae (Tabel 2). Hasil uji pengecatan gram fermentasi limbah kubis dengan perlakuan penambahan vitamin dan mineral adalah bentuk oval, soliter, dan gram positif (yeast). Yeast yang ditemukan memiliki warna putih, bentuk yang bulat/oval, dan memiliki spora berdiameter 5-10 $\mu \mathrm{m}$. Hal ini didukung oleh Suryaningsih et al. (2018) menyatakan bahwa yeast memiliki warna putih agak krem, berbentuk oval, dan memiliki diameter 3,5 $\mu \mathrm{m}$. Achmad et al. (2015) menyatakan yeast memiliki bentuk oval dan soliter jika diamati. Yeast tidak mudah mati dengan kondisi lingkungan yang stress sehingga bisa hidup lebih panjang dari pada mikroba lainnya. Anggrayeni et al. (2019) menyatakan bahwa yeast bersifat toleran terhadap kondisi lingkungan dengan kadar air rendah maupun tinggi.

Dari hasil morfologi yang telah dilakukan dapat diketahui bahwa warna pengecatan yang diidentifikasi sebagai Saccharomyces cerevisiae cenderung ungu dan bentuk yang dimiliki adalah oval, soliter, gram positif yang merupakan yeast dengan jenis Saccharomyces cerevisiae. Hal ini didukung oleh Hidayanti, et al. (2011) menyatakan bahwa Saccharomyces cerevisiae memiliki bentuk oval. Gram positif ditandai oleh timbulnya warna violet pada pengecatan gram. Menurut Suryaningsih, et al. (2018) warna violet muncul dari hasil reaksi reduksi memudarkan warna sel yeast yang hidup dan oksidasi yang menyebabkan munculnya warna violet.

Tabel 2. Hasil identifikasi yeast pada limbah kubis terfermentasi dengan penambahan vitamin dan mineral berdasarkan hasil morfologinya

\begin{tabular}{cccccc}
\hline Variabel & \multicolumn{5}{c}{ Perlakuan } \\
\cline { 2 - 6 } & T0 & T1 & T2 & T3 \\
\hline U1 & Saccharomyces & Saccharomyces & Saccharomyces & Saccharomyces & Saccharomyces \\
& cerevisiae & cerevisiae & cerevisiae & cerevisiae & cerevisiae \\
U2 & Saccharomyces & Saccharomyces & Saccharomyces & Saccharomyces & Saccharomyces \\
& cerevisiae & cerevisiae & cerevisiae & cerevisiae & cerevisiae \\
U3 & Saccharomyces & Saccharomyces & Sacharomyces & Saccharomyces & Saccharomyces \\
& cerevisiae & cerevisiae & cerevisiae & cerevisiae & cerevisiae \\
\hline
\end{tabular}

\section{Keterangan :}

$\mathrm{TO}=$ Fermentasi limbah kubis tanpa penambahan vitamin dan mineral

$\mathrm{T} 1=$ Fermentasi limbah kubis dengan penambahan vitamin dan mineral 2,5\%

$\mathrm{T} 2=$ Fermentasi limbah kubis dengan penambahan vitamin dan mineral 5\%

$\mathrm{T} 3=$ Fermentasi limbah kubis dengan penambahan vitamin dan mineral 7,5\%

T4= Fermentasi limbah kubis dengan penambahan vitamin dan mineral 10\%

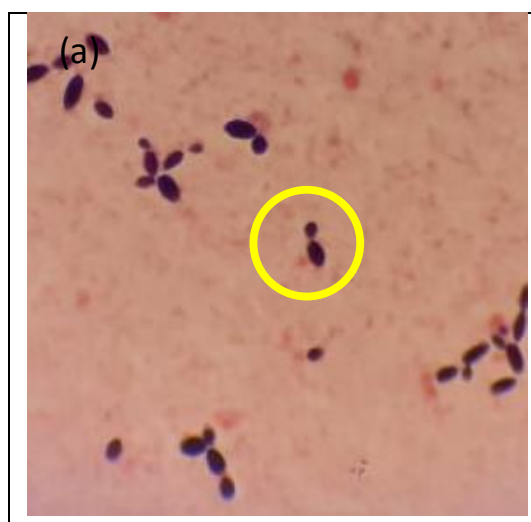

Saccharomyces cerevisiae

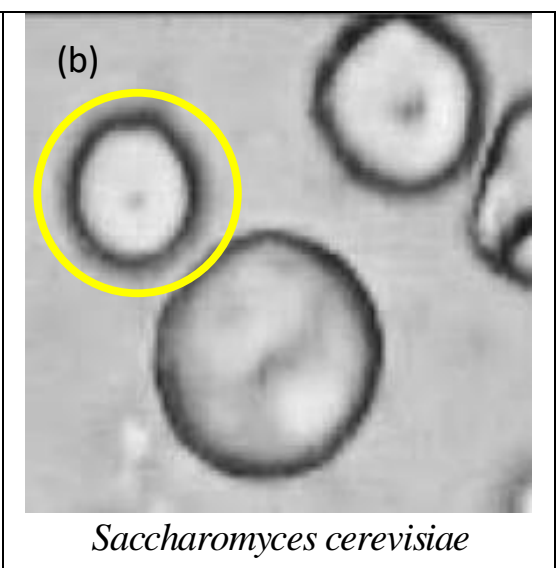

Saccharomyces cerevisiae

Gambar 1. Perbandingan Gambar Yeast

Saccharomyces cerevise (Berdasarkan morfologinya): Bentuknya oval, soliter, gram positif

Keterangan: Yeast. (a) Pengecatan gram yeast, perbesaran 10000x (Gambar Hasil Penelitian Utama et al., 2019); (b) Mikroskop cahaya, perbesaran 1000x (Kustyawati et al, 2013). 


\section{KESIMPULAN}

Berdasarkan hasil penelitian dapat disimpulkan bahwa penambahan vitamin dan mineral sebanyak $10 \%$ mampu meningkatkan kualitas limbah kubis fermentasi dilihat dari kandungan total jamur dan jenis yeast.

\section{UCAPAN TERIMAKASIH}

Ucapan terima kasih kepada Lembaga Penelitian dan Pengabdian kepada Masyarakat atas fasilitasinya dalam penugasan kegiatan Riset Pengembangan dan Penerapan (RPP) sumber dana selain APBN Universitas Diponegoro Tahun 2019, No: 329-36/UN7.P4.3/PP/2019.

\section{DAFTAR PUSTAKA}

Abdianti, B., A. Suprihadi, \& Wijanarka. 2017. Produk inuliase oleh khamir Pichia manshurica DUCC Y-015 pada tepung umbi dahlia (Dahlia variabilis willd.) dengan variasi konsentrasi MnSo4.H2O dan waktu inkubasi. J Biologi 6(3):22-30.

Achmad, J., N. Widaningsih, \& E. Mindarto. 2015. Pengaruh lama penyimpanan hasil fermentasi pelepah sawit oleh Trichoderma $s p$ terhadap derajat keasaman $(\mathrm{pH})$, kandungan protein kasar dan serat kasar. Ziraa'ah 4(3):1-10. DOI: 10.31602/zmip. v40i3.239.

Aliya, H., N. Maslakah, T. Numprapi, A. Buana, \& N. Yola. 2015. Pemanfaatan asam laktat hasil fermentasi limbah kubis sebagai pengawet anggur dan stroberi. J Bioedukasi 9(1):23-28. DOI: 10.20961/bioedukasi-uns. v9i1.3878

Angkasa, S. 2017. Ramuan Pakan Ternak. Penebar Swadaya. Jakarta.

Anggrayeni, Y. T., Wijanaka, \& K. Endang. 2019. Isolasi dan identifikasi morfologi serta biokimia khamir hasil isolasi dari buah tomat (Lycopersicum esculentum) yang berpotensi menghasilkan bioetanol. J Bioma 21(2):16-24. DOI: 10.14710/bioma.21.1.16-24

Astuti, H. K. \& D. K. Nengah. 2013. Efektifitas pertumbuhan jamur tiram putih (Pleurotus ostreatus) dengan variasi media kayu sengon (Paraserianthes falcataria) dan sabut kelapa (Cocos nucifera). J. Sains dan Seni Pomits. 2(2): 2337 - 3520. DOI: 10.12962/j23373520.v2i2.3955
Brummer, M, C. J. Van Rensburg, \& C. A. Moran. 2010. Saccharomyces cerevisiae cell wall products: the effects on gut morphology and performance of broiler. Journal of Animal Science 40 (1):14-21. DOI: 10.4314/sajas. v40i1.54125

Bulele, T., F. Rares, \& P. John. 2019. Identifikasi bakteri patogen dengan pewarnaan gram pada penderita infeksi mata luar di rumah sakit mata Kota Manado. J e-Biomedik 7(1):30-36. DOI: 10.35790/ebm.7.1.2019. 22820.

Cici, M., H. Yanto, \& P. L. Tuti. 2019. Pengaruh penambahan dedak halus yang difermentasi dengan Saccharomyces cerevisiae dalam pakan terhadap pertumbuhan ikan biawan (Helostoma temminckii). J Borneo Akuatika 1(2):95-103. DOI: 10.29406/jba.v1i2.1830.

Edam, M. 2018. Pengaruh kombinasi konsentrasi $\mathrm{NaCl}$ dan lama fermentasi terhadap produksi asam laktat dari kubis (Brassica oleracea). J Penelitian Teknologi Industri 10(1):17-24.

DOI: 10.33749/jpti.v10i1.3953

El-Banna, A. A., M. A. El-Sahn, \& M. Shehata. 2011. Yeast producing killer toxins: An overview. J Fd Sci and Technol 8(2):41-53.

Embarsari, R. P., A. Taofik, \& F. Budy. 2015. Pertumbuhan dan hasil seledri (Apium graveolens $L$.) pada sistem hidroponik sumbu dengan jenis sumbu dan media tanam berbeda. J Agro 2(2):41-48.

Hastuti, S. D. 2012. Suplementasi $\beta$-glucan dari ragi roti (Saccharomyces cerevisiae) dalam pakan terhadap aktivitas fagositosis, aktivitas NBT, total protein plasma dan aktivitas aglutinasi darah ikan nila (Orechromis niloticus). J Depik 1(3):149155. DOI: 10.13170/depik.1.3.102.

Juwandi, M \& Fitriani. 2018. Evaluasi kandungan lemak kasar dan betn silase daun lamtoro pada level yang berbeda sebagai bahan pakan utama pakan komplit. J Bionature 19(2):112-117. DOI: 10.35580/bionature. v19i2.9728

Kurnia, F., M. Suhardiman, L. Stephani, \& T. Purwadaria. 2012. Peranan nano-mineral sebagai bahan imbuhan pakan untuk meningkatkan produktivitas dan kualitas produk ternak. J Wartazoza 22(4):187-193. DOI:10.14334/wartazoa.v22i4.968 
Kusmiati, K., A. Thontowi, \& N. Sukma. 2011. Efek sumber karbon berbeda terhadap produksi â-glukan oleh Saccharomyces Cerevisiae pada fermentor air lift. J Natur Indonesia 13(2):138-145. DOI: $10.31258 /$ jnat.13.2.138-145

Kustyawati, M., M. Sari, \& H. Teti. 2013. Efek fermentasi dengan Saccharomyces cerevisiae terhadap karakteristik biokimia tapioka. J Agritech 33(3):281-287. DOI: 10.22146/agritech.9549.

Hanung, C. D., R. Osmond, \& R. Hendro. 2013. Optimisasi produksi enzim lakase pada fermentasi kultur padat menggunakanjamur pelapuk putih Marasmius sp.: pengaruh ukuran partikel, kelembapan, dan konsentrasi $\mathrm{Cu}$. J Selulosa 3(2):67 -74. DOI: 10.25269/jsel.v3i02.45.

Hidayanti, Y. A., A. Kurniani, T. Marlina, \& H. Ellin. 2011. Kualitas pupuk cair hasil pengolahan feses sapi potong menggunakan Saccharomyces cerevisiae. J Ilmu Ternak 11(2):104-107.

DOI: 10.24198/jit.v11i2.387.

Manoppo, H. \& E. Magdalena. 2016. Penggunaan ragi roti (Saccharomyces cerevisiae) sebagai imunostimulan untuk meningkatkan resistensi ikan mas (Cyprinus carpio L) terhadap infeksi bakteri Aeromonas hydrophila. J Budidaya Perairan 4(3):37-47. DOI: 10.35800/bdp.4.3.2016.14945.

Nasiu, F., W. L. Salido, A. Tasse, Syamsuddin, A. Hairil \& I. Amilludin. 2020. Evaluasi kecernaan in vitro bahan kering dan bahan organik kulit singkong fermentasi sebagai bahan pakan ternak. J Ilmu dan Teknologi Peternakan Tropis 7(2):127-132. DOI: 10.33772/jitro.v7i2.11482

Nurdianto, M., C. S. Utama \& S. Mukodiningsih. 2015. Total jamur, jenis kapang dan khamir pellet ayam kampung super dengan penambahan berbagai level pollard berprobiotik. J Agripet 15(1):79084. DOI: 10.17969/agripet.v15i2.2379.

Nurika, I., N. Hidayat, \& A. R. Novianti. 2018. Pengaruh penambahan $\mathrm{CuSo}_{4}$ terhadap aktivitas enzim Schyzophyllum commune pada degradasi lignin limbah kulit kakao. J Teknologi Pertanian 19(1):25-32. DOI: 10.21776/ub.jtp.2018.019.01.3

Purwati, C. S. \& R. Danang. 2018. Perubahan suhu, $\mathrm{pH}$, protein kasar, dan serat kasar pada fermentasi biji kecipir (Psophocarpus tetragonolobus) dan tepung jagung dengan level jamur Trichoderma viride yang berbeda. J Ilmu dan Teknologi Peternakan Tropis 5(3):45-49. DOI: $10.33772 /$ jitro. v5i3.4766

Rostini, N., R. Hindersah, A. Harsono, \& M. K. Agustinus. 2019. Peran ekspolisakarida Azotobacter dan bahan organik untuk mengingatkan nodulasi dan biomassa kedelai pada dua ordo tanah. J Agro Indonesia 47(2):156-162. DOI: 10.24831/ jai.v47i2. 123328

Santosa, B., Wirawan, \& R.E. Muljawan. 2019. Pemanfaatan molase sebagai sumber karbon alternative dalam pembuatan nata de coco. J Teknologi Pangan 10(2):61-69. DOI: 10.35891/tp.v10i2.1641

Saraswati, D., Wijanarka., \& R. Isworo. 2017. Pengaruh $\mathrm{CaCl}_{2} 2 \mathrm{H}_{2} \mathrm{O}$ dan waktu inkubasi terhadap produksi Inulinase oleh Pichia manshurica DUCC Y-015 dalam substrat tepung umbi dahlia. J Biologi 6(3):31-37.

Sari, A. K. 2014. Analisis karakteristik gaya belajar VAK (Visual, Auditorial, Kinestetik) mahasiswa pendidikan informatika Angkatan 2014. J Ilmiah Edutic 1(1):1-12. DOI:10.21107/edutic.v1i1.395.g369

Siregar, M. S., M. Fuadi, \& Ainun. 2015. Pemanfaatan limbah kubis (Brassica oleracea) sebagai bahan pengawet ikan nila (Oreochromis sp). J Agrium 19(3):204-212.

Sumardi, Sutyarso, G. Susanto, T. Kurtini, M. Hartono, \& Rr. Etty. 2016. Pengaruh probiotik terhadap kolesterol darah pada ayam petelur (layer). J Kedokteran Hewan 10(2):128-131.

DOI: 10.21157/j.ked.hewan. v10i2.5042.

Suryaningsih, V., R. Ferniah, \& E. Kusdiyantini. 2018. Karakteristik morfologi, biokimia, dan molekuler isolat khamir IK-2 hasil isolasi dari jus buah sirsak (Annona 
muricata L.). Jurnal Akademika Biologi.। 7(1):18-25.

Usha, K. Y., K. Praveen, \& B. R. Reddy. 2014. Enhanced production of ligninolytic enzymes by a mushroom Stereum ostrea. J. Biotechnology Research International. Article ID 815495. DOI: 10.1155/2014/ 815495.

Utama, C. S., Zuprizal, C. Hanim, \& Wihandoyo. 2018. Probiotic testing of Lactobacillus brevis and Lactobacillus plantarum from fermented cabbage waste juice. Pakistan Journal of Nutrition. 7(7):323-328. DOI: 10.3923/pjn.2018.323.328.

Utama, C. S., Zuprizal, C. Hanim, \& Wihandoyo. $2018^{\text {b. }}$ Isolasi dan identifikasi bakteri asam laktat selulotik yang berasal dari kubis terfermentasi. J Aplikasi Teknologi Pangan 7(1):1-6. DOI:10.17728/jatp.2155
Wahyuni, A. E., V. C. Prakasita, T. E. Nahak, A. V. Tae, J. C. Ajiguna, S. L. Adrenalin, L. N. Imanjati, \& F. Ima. 2016. Peluang imbuhan pakan herbal-probiotik komersial "Promix ${ }^{\circledR}$ " sebagai pengganti antibiotic growth promoter (AGP) pada ayam pedaging yang diberi vaksin ND. J Sain Veterniner 37(2):180-184. DOI: 10.22146/ jsv.40375.

Wulandari, C. A., W. Hersoelistyorini \& Nurhidajah. 2017. Pembuatan tepung gadung (dioscorea hispidia dennst) melalui proses perendaman menggunakan ekstrak kubis fermentasi. Prosiding Seminar Teknologi Pangan, Universitas Muhammadiyah Semarang. Semarang, 30 September 2017. Hal. 423-430. 